УДК 342.951:351.82

DOI https: / / doi.org/10.32837/yuv.v0i6.2044

\author{
В. Ліпинський, \\ кандидат юридичних наук, доцент, \\ директор \\ Навчально-наукового інституту права та міжнародно-правових відносин \\ Університету митної справи та фінансів
}

\title{
АДМІНІСТРАТИВНИЙ ШТРАФ ЗА ПОРУШЕННЯ МИТНИХ ПРАВИЛ: ПРАВОВА ОСНОВА ТА ПЕРСПЕКТИВИ ВДОСКОНАЛЕННЯ ЇХ ТЛУМАЧЕННЯ
}

\begin{abstract}
Постановка проблеми та завдання дослідження. Адміністративна відповідальність за порушення митних правил $€$ фундаментальним інструментом митного адміністрування, який сприяє дотриманню митного законодавства, забезпечуючи невідворотність негативних фінансових та організаційних наслідків для фізичних осіб та підприємств, які вчинили порушення митних правил. Адміністративна відповідальність за порушення митних правил виражається передусім у накладенні на правопорушників передбачених митним законодавством адміністративних стягнень, серед яких слід назвати такі: попередження - офіційне застереження правопорушника від вчинення порушень митних правил у майбутньому, що виноситься у формі постанови про накладення адміністративного стягнення; штраф - покладення на правопорушника обов'язку сплатити до державного бюджету грошові кошти у сумі, яка визначається митним законодавством залежно від виду та характеру вчиненого правопорушення; конфіскація - примусове безоплатне вилучення за рішенням суду на користь держави безпосередніх предметів порушення митних правил та у встановлених законом випадках товарів та транспортних засобів, 3 використанням яких вчинялось митне правопорушення
\end{abstract}

(ст. ст. 461-465 MK України) [1]. Однак за підсумками вивчення положень митного законодавства про ці адміністративні стягнення очевидним $€$ те, що вони не є досконалими, про що свідчить насамперед те, що чимало теоретико-правових та практико-прикладних питань постають у контексті застосування штрафів. Передусім не викликає схвалення неможливість досягти пропорційності митних адміністративних штрафів та індивідуалізувати їх у зв'язку з усіма обставинами справи, що не є сумісним із верховенством права, а також не узгоджується 3 міжнародними стандартами, позитивним зарубіжним досвідом та найкращим доробком наукового співтовариства. Водночас позитивного зрушення можна досягти навіть без внесення змін та доповнень до митного законодавства шляхом спрямування зусиль на його належне тлумачення.

Аналіз публікацій та виклад основних положень дослідження. Джерелознавчий аналіз вищенаведених питань охопить нормативно-правові документи найбільш розвинених держав, міжнародні договори та роз'яснювальні публікації фахівців відповідних міжнародних організацій, а також наукові праці з питань митного адміністрування українських учених, серед яких слід назвати А.Є. Плетньову. 
Висвітлюючи поточний стан правового регулювання штрафів як адміністративних стягнень за митним законодавством та визначаючи його простір для вдосконалення, перш за все наведемо декілька прикладів адміністративних правопорушень, що караються штрафом, та розміри цих грошових стягнень. Зокрема, штраф передбачений за:

- недекларування товарів, транспортних засобів комерційного призначення, що переміщуються через митний кордон, тобто незаява про них за встановленою формою точних та достовірних відомостей (наявність, найменування або назва, кількість тощо), які підлягають обов'язковому декларуванню у разі переміщення через митний кордон - 100\% вартості цих товарів, транспортних засобів з їх конфіскацією (ч. 1 ст. 472 МК України);

- перешкоджання посадовій особі митного органу під час здійснення нею митного контролю або провадження у справі про контрабанду чи порушення митних правил у доступі до товарів, транспортних засобів, документів - 100 неоподатковуваних мінімумів доходів громадян (ч. 1 ст. 474 MK України);

- повторне перешкоджання в доступі до товарів, транспортних засобів, документів, а також перешкоджання посадовій особі митного органу або невиконання ії вимог під час перевірки обліку товарів, що переміщуються через митний кордон та/або перебувають під митним контролем; документальної перевірки дотримання вимог митного законодавства - 500 неоподатковуваних мінімумів доходів громадян (ч. 2 ст. 474 MK України);

- ухилення від сплати митних платежів:

1) заява в митній декларації задля неправомірного звільнення від сплати митних платежів чи зменшення ї розміру неправдивих відомостей щодо істотних умов зовнішньоекономічного договору (контракту), ваги (з урахуванням допустимих втрат за належних умов зберігання і транспортування) або кількості, країни походження, відправника та/або одержувача товару, неправдивих відомостей, необхідних для визначення коду товару згідно з УКТ ЗЕД, а також його митної вартості;

2) надання задля цього митному органу документів, що містять такі відомості;

3) несплата митних платежів у строк, установлений законом;

4) інші протиправні діï, спрямовані на ухилення від сплати митних платежів;

5) використання товарів, стосовно яких надано пільги щодо сплати митних платежів, в інших цілях, ніж ті, у зв'язку 3 якими було надано такі пільги, - 300\% несплаченої суми митних платежів (ч. 1 ст. 485 MK України) [1].

Привертає увагу у зв'язку з цим те, що за приписами ч. 1 ст. 489 MK України посадова особа митних органів під час розгляду справи про порушення митних правил зобов'язана з'ясувати, чи є обставини, що пом'якшують та/або обтяжують відповідальність [1], однак можливість ї урахування під час вибору адміністративного стягнення $є$ ілюзорною через установлення митним законодавством абсолютно визначених санкцій.

Звищевикладеноговипливаєшироке використання в адміністративноделіктному митному законодавстві підходу до визначення суми штрафу, за яким вона або є твердою, або вираховується залежно від значень, які характеризують допущене фізичною особою чи підприємством порушення митних правих (сума несплачених митних платежів, вартість товарів тощо). Водночас за цього підходу не встановлюються нижня та верхня межі штрафів, що виключає гнучкість у визначенні розміру стягнення, що не цілком узгоджується 3 міжнародними стандартами.

Зокрема, за змістом ч. 1 ст. 42 Митного кодексу ЄC, кожна держава-член 
повинна передбачити санкції за недотримання митного законодавства, які мають бути дієвими, пропорційними й стримувальними [2]. Стандартним правилом 23 Конвенції про гармонізацію та спрощення митних процедур встановлюється, що ступінь суворості або обсяг санкцій, застосовуваних під час адміністративного врегулювання митного правопорушення, залежить від ступеня серйозності або значимості здійсненого митного правопорушення та від попередньої діяльності відповідної особи, пов'язаної з митним адмініструванням [3]. Деталізуючи зміст та призначення цього загального правила, Всесвітня митна організація звертає увагу на те, що воно закріплює принцип пропорційності та вимагає виключити накладення на правопорушників надмірно суворих стягнень, вид і розмір яких мають відповідати тяжкості правопорушення, недоотриманим доходам державного бюджету та індивідуальній історії взаємодії правопорушника 3 митними органами [4, с. 17]. Ці вимоги знайшли відображення у п. п. 3.2-3.3 Угоди про спрощення процедур торгівлі (додаток до Протоколу про внесення змін до Марракеської угоди про заснування Світової організації торгівлі), за якими штрафні санкцій за порушення митних законів, підзаконних нормативно-правових актів або процедурних вимог мають застосовуватись лише до особи (осіб), відповідальної (відповідальних) за порушення згідно 3 його законодавством, а також залежати від фактів та обставин справи і відповідати ступеню та тяжкості порушення [5].

За справедливим зауваженням, висловленим А.Є. Плетньовою, за українським митним законодавством у разі вчинення порушення митних правил, яке істотно не загрожує охоронюваним суспільним відносинам, до правопорушника можуть бути застосовані непропорційно великі санкціі. Наприклад, недекларування товарів, транспортних засобів комер- ційного призначення, що переміщуються через митний кордон України, тобто незаява за встановленою формою точних та достовірних відомостей (наявність, найменування або назва, кількість тощо) про товари, транспортні засоби комерційного призначення, які підлягають обов'язковому декларуванню у разі переміщення через митний кордон України, тягне за собою накладення штрафу в розмірі 100 відсотків вартості цих товарів, транспортних засобів $3 \mathrm{koн-}$ фіскацією зазначених товарів, транспортних засобів. Як слушно зазначає вчена, у цьому разі може мати місце технічна друкарська помилка або ситуація, коли недостовірні відомості були представлені декларанту третьою особою (постачальником, виробником, контрагентом тощо), тобто є добросовісна необізнаність. Тоді подібна санкція, як видається, має на меті максимальне покарання правопорушника, а не сприяння розвитку зовнішньоекономічної діяльності. Як показує судова практика, в зазначених випадках суди нерідко застосовують ст. 22 КпАП, скасовуючи постанови митних органів про притягнення до адміністративної відповідальності за порушення митних правил у зв'язку 3 малозначністю вчиненого [6, с. 76-77]. Водночас судова практика з позицією про наявність у судів повноважень скасовувати постанови митних органів про притягнення до адміністративної відповідальності за порушення митних правил у зв'язку 3 малозначністю $€$ неусталеною та не підтримується найвищим судом у вітчизняній судовій системі. Йдеться про висновки Верховного Суду щодо того, що втручанням в дискреційні повноваження компетентного суб'єкта владних повноважень визнається звільнення порушника від адміністративної відповідальності адміністративним судом у зв'язку з малозначністю вчиненого адміністративного правопорушення, тоді як працівниками поліції 
на нього було накладено адміністративне стягнення. Обгрунтуванням цього твердження послугувало те, що вирішення питання про притягнення особи до адміністративної відповідальності є виключною компетенцією працівників підрозділів Національної поліції України, а адміністративний суд, перевіряючи рішення, дію чи бездіяльність суб'єкта владних повноважень на відповідність закріпленим ч. 3 ст. 2 КАС України критеріям, не втручається у дискрецію (вільний розсуд) суб'єкта владних повноважень поза межами перевірки за названими критеріями, адже завдання адміністративного судочинства полягає не у забезпеченні ефективності державного управління, а в гарантуванні дотримання прав та вимог законодавства, інакше було би порушено принцип розподілу влади (Постанова Верховного Суду від 31 жовтня 2019 р. у справі № 266/3228/16-а) [7]. 3 огляду на це видається безальтернативною науковою позицією приєднання до точки зору А.Є. Плетньової про те, що необхідно ретельно опрацювати критерії пом'якшуючих факторів для встановлення судом малозначності правопорушення для того, щоб його використання по відношенню до тих чи інших порушників було прозорим, обгрунтованим i справедливим. Також безсумнівною видається обгрунтованість думки вченої про те, що необхідне подальше опрацювання питання щодо пропорційності діючих видів та розмірів адміністративних санкцій, передбачених за порушення митних правил, що позитивно вплине на ефективність виконання державою завдань у сфері зовнішньоекономічної діяльності [6, с. 77].

На доповнення до вищевикладеного зазначаємо, що нагальна необхідність тлумачення адміністративно-деліктних положень митного законодавства для забезпечення пропорційності адміністративних стягнень шляхом їх максимального пристосування до особливостей обставин справи та становища правопорушника підтверджується тим, що цей постулат реалізований у міжнародних стандартах та рекомендаціях, актах митного законодавства та роз'яснювальних матеріалах митних органів найбільш розвинених зарубіжних країн. Неприпустимим шляхом державного реагування на порушення митних правил $€$ накладання адміністративних стягнень із незмінними значеннями без належного врахування під час визначення їх виду та розміру обставин, які пом'якшують та обтяжують адміністративну відповідальність фізичних осіб та підприємств.

Наприклад, Всесвітня митна організація дотримується позиції щодо того, що якщо митне правопорушення виникає внаслідок неправдивих відомостей, наведених у товарній декларації, то відповідальність декларанта може бути обмежена, якщо він просто відтворив інформацію, повідомлену йому його митним брокером або уповноваженим економічним оператором, і вжив розумних заходів для забезпечення достовірності інформації [4, с. 6]. За стандартним правилом 24 Спеціального додатку Н до Конвенції про спрощення та гармонізацію митних процедур, коли в декларації на товари зазначені недостовірні дані та декларант може довести, що ним було вжито всіх необхідних заходів для зазначення точної і правильної інформації, митна служба бере цю обставину до уваги під час вирішення питання про застосування санкції [3]. Крім того, приклад обставини, яка має послабити стягнення за порушення митних правил, передбачає п. 3.6 Угоди про спрощення процедур торгівлі (Протокол про внесення змін до Марракеської угоди про заснування Світової організації торгівлі), відповідно до якого коли особа добровільно розкриває митній адміністрації члена обставини порушення митного закону, підзаконного нормативно-правового акта чи процедурної вимоги до виявлення порушення митною адміні- 
страцією, то члену рекомендується за необхідності розглядати цей факт як потенціальну пом'якшуючу обставину в контексті встановлення штрафних санкцій для цієї особи [5].

Зарубіжний досвід, який відповідає вищенаведеним стандартам, відображений, зокрема, у положеннях американського митного законодавства та керівництвах, виданих Митною та прикордонною службою США. Насамперед зауважимо, що розмір грошового стягнення за митне правопорушення у зазначених джерелах поставлений у залежність від характеру вини правопорушника. Йдеться про те, що за змістом положень секції 1592 Кодексу законодавства США за порушення митних правил встановлюється штраф у таких розмірах та межах:

- у разі шахрайського правопорушення - від 5- до 8-кратного розміру недоотриманих митних платежів або, якщо правопорушення не вплинуло на справляння митних платежів, 50-80\% митної вартості товарів, але не більше суми, яка становить їх внутрішню ринкову вартість;

- за правопорушення, пов'язане 3 грубою недбалістю, - від 2,5- до 4-кратного розміру недоотриманих митних платежів або, якщо правопорушення не вплинуло на справляння митних платежів, 25-40\% митної вартості товарів, але не більше суми, яка становить їх внутрішню ринкову вартість;

- за правопорушення, пов'язане зі звичайною недбалістю, - від 0,5- до 2-кратного розміру недоотриманих митних платежів або, якщо правопорушення не вплинуло на справляння митних платежів, 5-20\% митної вартості товарів, але не більше суми, яка становить ї внутрішню ринкову вартість [8, с. 29].

Також від посадових осіб цього державного органу вимагається забезпечувати пропорційність адміністративних стягнень за порушення митних правил шляхом урахування пом'якшуючих обставин, серед яких слід назвати зв'язок правопорушення 3 комплементарною помилкою митних органів, співпрацю під час розслідування, негайне виправлення порушення, позитивну історію взаємодіі 3 митними органами, добросовісну помилку у складних питаннях митного адміністрування через недосвідченість. На противагу до пом'якшуючих обставин, відповідальність фізичних осіб та підприємств може обтяжуватись деякими обставинами, зокрема перешкоджанням розслідуванню утриманням доказів, введенням посадових осіб митних органів в оману, негативною історією взаємодіiі з митними органами [8, с. 28].

Відповідність адміністративних стягнень за порушення митних правил, тяжкість та наслідки цих порушень, як особливості індивідуального становища правопорушника, а також прагнення до застосування якомога більш м'яких заходів державного реагування на ці правопорушення, достатніх для досягнення їх цілей, визначає правомірність накладених адміністративних стягнень митними органами Республіки Ірландія. У цій країні нормативно-правовими документами встановлено, що адміністративні стягнення за порушення митних правил не мають застосовуватись у випадках широкого дотримання приписів митного законодавства або лише за перше правопорушення. Перш ніж приймати рішення про стягнення штрафних санкцій, митні органи мають виносити попередження, взаємодіяти 3 підприємствами для вирішення їх проблем, що стали перешкодою для виконання їх обов'язків перед митними органами. Більш суворими заходи реагування мають бути лише в разі відмови від співпраці або неможливості без штрафів та конфіскації запобігти повторенню порушень [9, с. 3].

Більш того, разом із визначенням суми грошового стягнення за порушення митних правил у визначених законом межах залежно від усіх обставин справи, що визначають 
тяжкість правопорушення та ступінь вини правопорушника, у найбільш розвинених зарубіжних країнах допускається послаблення адміністративних стягнень за виняткових обставин.

Так, положення про можливість пом'якшення або скасування стягнення за порушення митних правил митними органами США закріплено ст. 1618 розд. 19 Кодексу законодавства США, за якою коли щодо особи застосовано або порушується питання про застосування штрафу конфіскації транспортного засобу, товарів або багажу, то вона може звернутись до державного секретаря казначейства за пом'якшенням стягнення або прощенням порушення митних правил, якщо це порушення було допущено без цілеспрямованого невиконання обов'язків, прагнення мінімізувати суму митних платежів або порушити порядок переміщення через митний кордон. За цих обставин або в разі виявлення державним секретарем казначейства інших підстав пом'якшити або зняти відповідальність з особи він приймає рішення про це з умовами, які він вважає розумними та справедливими, або припиняє провадження про порушення митних правил. При цьому державний секретар казначейства може дозволити анулювання угоди 3 особою в разі порушення нею будь-якого положення угоди. Для забезпечення послідовних, обгрунтованих та справедливих рішень щодо пом'якшення або звільнення від відповідальності за порушення митних правил державний секретар казначейства оприлюднює керівні принципи, що встановлюють стандарти для встановлення підстав та процедурних засад прийняття відповідних рішень, зокрема про анулювання угод (ст. 1623 розд. 19 Кодексу законодавства США) [10].

Аналогічний механізм діє за законодавством Сполученого Королівства. Воно не визначає підстав для пом'якшення адміністративних стягнень, що обумовлює необхідність вирішувати питання про виключність обставин для послаблення відповідальності за допущене правопорушення відповідно до внутрішнього переконання посадових осіб митного органу. Податкова та митна служба Сполученого Королівства роз'яснила, що такими обставинами можуть бути події особистого характеру у людини, яка самостійно веде підприємницьку діяльність або має вирішальний вплив на бізнес-рішення (наприклад, тяжка хвороба або реабілітація після тяжкої хвороби ї або члена іï сім’i); викрадення або знищення первинних документів, записів бухгалтерського обліку 3 повідомленням про це місцевого податково-митного територіального підрозділу; несправність комп'ютерів або програмного забезпечення, що заважає виконанню вимог про декларування або процедурних вимог. При цьому береться до уваги те, чи могла особа передбачити обставини, що призвели до порушення, і якщо так, то чи вжила вона усіх можливих заходів для уникнення правопорушення; чи зв'язалась особа з митними органами 3 проханням про допомогу чи пораду; чи надала особа достатнього пріоритету виконанню обов'язків, що випливають з митного законодавства. Водночас митні органи врахують історію зовнішньоекономічних операцій, ступінь співпраці з митними органами під час розслідування, а також заходи, вжиті для унеможливлення подібних порушень у подальшій діяльності. Конкретна частка зменшення накладеного грошового стягнення визначається відповідно до внутрішнього переконання на основі наведених обставин. Водночас чинниками, що можуть послабити стягнення, не вважаються, зокрема, добросовісність фізичної особи або підприємства; відсутність у них коштів для сплати митних платежів або санкцій; недоотримання дрібних сум митних платежів [11].

Зауважимо, що адміністративна відповідальність за порушення митних правил також диференціюється 
залежно від того, чи воно виявлене за підсумками розслідування митного органу або його добровільного визнання фізичною особою чи підприємством. Так, за американським митним законодавством, особа, яка добровільно розкриє обставини вчинення нею правопорушення, до початку розслідування відповідного правопорушення або не знаючи про таке розслідування, може розраховувати на послаблення або навіть звільнення від відповідальності у таких випадках:

- якщо вчинилось митне правопорушення через недбалість чи грубу недбалість та якщо має місце втрата доходів державним бюджетом, то правопорушник сплачує відсоток від суми недоотриманих митних платежів до дня повного розрахунку;

- якщо вчинилось митне правопорушення через недбалість чи грубу недбалість, коли державний бюджет лише потенційно може втратити доходи, сплата грошових стягнень не вимагається;

- якщо вчинилось шахрайське митне правопорушення, стягнення являє собою 1-кратний розмір недоотриманих митних платежів, а якщо правопорушення не вплинуло на справляння митних платежів, то стягнення становить 10\% митної вартості товарів [8, с. 29].

Висновки 3 дослідження. Підсумовуючи вищевикладене, маємо підстави стверджувати, що, незважаючи на буквальний зміст положень митного законодавства про застосування штрафів за порушення митних правил, воно має тлумачитися з урахуванням принципу пропорційності, який вимагає забезпечення відповідності адміністративних стягнень за порушення митних правил тяжкості та наслідкам цих порушень, ступеню вини правопорушника з урахуванням усіх обставин справи, що вимагає обмеження вжиттям якомога більш м'яких заходів державного реагування на ці правопорушення, достатніх для досягнення цілей адміністративних стягнень за порушення митних правил. 3 огляду на пріоритетність верховенства права перед приписами позитивного законодавства абсолютно визначений розмір штрафів за порушення митного законодавства не може знімати із суб'єктів правозастосування обов'язок, керуючись принципами права, зважувати ступінь інтенсивності державних репресивно-превентивних заходів 3 урахуванням особливих обставин справи. Як показує досвід найбільш розвинених країн, обтяжуючими обставинами можна вважати, зокрема, негативну історію взаємодії 3 митними органами, умисне перешкоджання розслідуванню митних органів утриманням доказів чи введенням посадових осіб митних органів в оману. Натомість обставинами, що пом'якшують адміністративну відповідальність за порушення митних правил, слід визнавати вчинення правопорушення вперше 3 необережною формою вини або без значних наслідків для державного бюджету через недоотримання доходів; тяжкі події особистого характеру у людини, яка самостійно веде підприємницьку діяльність або має вирішальний вплив на бізнес-рішення; вжиття усіх можливих заходів для уникнення правопорушення, зокрема звернення до митних органів з проханням про консультацію чи іншу допомогу; добросовісну помилку у складних питаннях митного адміністрування через недосвідченість; зв'язок правопорушення 3 комплементарною помилкою митних органів, співпрацю під час розслідування митних органів; негайне виправлення порушення; позитивну історію взаємодії з митними органами.

У статті обтрунтовано нагальну необхідність тлумачення положень митного законодавства про адміністративний штраф так, щуоб його розмір відповідав обставинам справи щодо тяжкості правопорушення, ступеня вини 
правопорушника та його індивідуального становища, на противагу механічному застосуванню иього адміністративного стягнення митними органами та судами у встановленому законом єдиному можливому розмірі. Застосовуючи нормативно-догматичний, системний, порівняльно-правовий та інші методи наукового пізнання, автор висловлюе аргументи на користь того, що, незважаючи на буквальний зміст положень митного законодавства про застосування штрафів за порушення митних правил, вони мають тлумачитися з урахуванням принцииу пропориійності, який вимагає забезпечення відповідності адміністративних стягнень за порушення митних правил обставинам справи, а також обмеження вжиттям якомога більш м'яких заходів державного реагування на иј правопорушення, достатніх для досягнення цзілей адміністративних стягнень за порушення митних правил. 3 огляду на пріоритетність верховенства права перед приписами позитивного законодавства абсолютно визначений розмір итрафів за порушення митного законодавства не може знімати із суб'єктів правозастосування обов'язок, керуючись принципами права, зважувати ступінь інтенсивності державних репресивно-превентивних заходів з урахуванням особливих обставин справи. Як показує досвід найбільш розвинених країн, обтяжуючими обставинами можна вважати, зокрема, негативну історію взаємодіі з митними органами, умисне перешкоджання розслідуванню митних органів утриманням доказів чи введенням посадових осіб митних органів в оману. Натомість обставинами, що пом'якшують адміністративну відповідальність за порушення митних правил, слід визнавати вчинення правопорушення вперше
3 необережною формою вини або без значних наслідків для державного бюджету через недоотримання доходів; тяжкі події особистого характеру у людини, яка самостійно веде підприємнищьку діяльність або має вирішальний вплив на бізнес-рішення; вжиття усіх можливих заходів для уникнення правопорушення, зокрема звернення до митних органів з проханням про консультацію чи іншу допомогу; добросовісну помилку у складних питань митного адміністрування через недосвідченість; зв'язок правопорушення з комплементарною помилкою митних органів, співпрацюю під час розслідування митних органів; негайне виправлення порушення; позитивну історію взаємодії з митними органами.

Ключові слова: адміністративна відповідальність за порушення митних правил, адміністративний штраф, порушення митних правил, пропорційність адміністративних стягнень, штраф за порушення митних правил.

Lipynskyi V. Administrative fine for violation of customs regulations: legal basis and prospects for improvement of its interpretation

The article argues that there is an urgent need to interpret the provisions of the customs legislation on administrative fines in a way that ensures correspondence of its amount to circumstances of the case relating to the gravity of the offense, the degree of guilt of the offender and his situation, as opposed to the mechanical imposition of this administrative penalty by customs authorities and courts in single unchangeable amount prescribed by law. Applying normative-dogmatic, systemic, comparative-legal and other methods of scientific research, the author maintains that, despite the literal content of the provisions of customs legislation on the application of fines for violations of customs 
rules, they should be interpreted taking into account the principle of proportionality, which requires limiting punishments to the mildest possible measures suitable enough to respond to particular offenses. Given the priority of the rule of law over the provisions of positive law, a definite amount of fines for violation of customs legislation cannot relieve governmental authorities of the obligation, to weigh the intensity of state repressive measures in light of special circumstances. As the experience of the most developed countries shows, aggravating circumstances can be considered which are, in particular, the negative history of cooperation with customs authorities, intentional obstruction of the investigation of customs authorities by withholding evidence or misleading customs officials. Instead, in determination of appropriate amount of fine for violating customs regulations one should consider mitigating circumstances such as commitment of an offense for the first time with a negligent form of guilt or without significant consequences for the state budget due to lack of revenue; severe events of a personal nature in life of a person who independently conducts business activities or has a decisive influence on business decisions; taking all possible steps to avoid the offense, including requesting advice or other assistance from the customs authorities; bona fide error in complex issues of customs administration due to inexperience; connection of the offense with a complementary error of the customs authorities, cooperation during the investigation of the customs authorities; immediate correction of the violation; positive history of interaction with customs authorities.

Key words: administrative fine, administrative liability for violation of customs regulations, fine for violation of customs regulations, proportionality of administrative penalties, violation of customs regulations.

\section{Література}

1. Митний кодекс України : Закон України від 13 березня 2012 р. № 4495VI. Дата оновлення: 24 жовтня 2020 р. URL: https: / / zakon.rada.gov.ua/laws / show/4495-17\#Text.

2. Регламент Європейського Парламенту і Ради (EC) про встановлення Митного кодексу Союзу від 9 жовтня 2013 р. № 952/2013. Дата оновлення: 23 грудня 2016 p. URL: https: / / zakon.rada.gov.ua/ laws / show/984_009-13\#Text.

3. Міннародна конвенція про спрощення $i$ гармонізацію митних прощедур (Кіотська конвенція) : міжнародний документ Рада Митного Співробітництва від 18 травня 1973 р. Дата оновлення: 26 червня 1999 p. URL: https: / / zakon.rada. gov.ua/laws/show/995_643/conv\#o1328.

4. World Customs Organization (2000). Kyoto Convention - Guidelines to Specific Annex H - Chapter 1: Customs Offences. URL: http: / / wrw.wcoomd.org / / media / wco / public/global/pdf/topics / wto-atf / dev/rkc-guidlines-sa-h1.pdf.

5. Протокол про внесення змін до Марракеської угоди про заснування Світової організації торгівлі. Угода про спрощення процедур торгівлі : міжнародний документ Світової організації торгівлі від 27 листопада 2014 p. URL: https:/ / zakon.rada.gov.ua/laws / show/981_053\#Text.

6. Плетньова А.Є. Сучасна проблематика адміністративної відповідальності за порушення митних правил. Актуальні проблеми вітчизняної юриспруденцї. 2020. № 1. C. 74-77.

7. Постанова Верховного Суду про скасування постанови про притягнення до адміністративної відповідальності від 31 жовтня 2019 р. у справі № 266/3228/16-a. URL: http://reyestr. court.gov.ua/Review/85323291.

8. U.S. Customs and Border Protection (2020). Customs Administrative Enforcement Process: Fines, Penalties, Forfeitures and Liquidated Damages - an informed compliance publication. URL: https: / / wwr.cbp.gov/sites / default / files / assets / documents / 2020-Feb / ICPFines-Penalties-Forfeitures-Liq-Damages2004-Final.pdf. 
9. Irish Tax and Customs (2016). Manual on Application of Administrative Penalties for Infringements of Customs Rules (Reviewed June 2016). URL: https: / / ww revenue.ie / en / tax-professionals / $\mathrm{tdm} / \mathrm{customs} / \mathrm{customs-administrative-}$ penalties / customs-administrativepenalties-20160617123920.pdf.

10. United States Code - Title 19 Customs Duties - Chapter 4. TARIFF ACT OF 1930 - Subtitle III. Administrative
Provisions-PartV.EnforcementProvisions.URL: https: / / www.law.cornell.edu/uscode / text / 19 / chapter-4 / subtitle-III / part-V.

11. HM Revenue\& Customs (2020). Notice 301: civil penalties for contraventions of customs law (Updated 23 September 2020). URL: https: / / www.gov.uk/government / publications / excise-notice-301-civilpenalties-for-contraventions-of-customslaw / excise-notice-301-civil-penalties-forcontraventions-of-customs-law. 